\title{
Pengaruh Beban Kerja Pada Tingkat Stress Kerja Karawan Yang Berdapak Pada Motivasi Kerja Dan Kinerja Karyawan Hotel di Jember
}

\author{
Faozen $^{1}$ \\ Universitas Muhammadiyah Jember, Indonesia \\ Email : faozen@unmuhjember.ac.id
}

\begin{abstract}
Abstrak
Tingginya beban kerja menjadi menjadi sebab stress kerja karyawan meningkat, hal ini tidak baik bagi perusahaanterutama pada tingkat motivasi kerja karayawan dan kinerja karyawan mengalamami kemunduran (penurunan) beban kerja perlu diukur supayan tingkat stress yang ingin ditimbulkan berpengaruh dengan baik, secara umum stress kerja terbagi menjadi dua diantaranya stress berpengaruh positif dan stress berpengaruh nigatif.Kinerja karyawan merupakan bentuk respon dari beban kerja yang diberikan oleh perusahaan pada karyawannya. Penelitian ini bertujuan untuk menguji apakah variabel beban kerja terhadap stress kerja, motivasi kerja, kinerja karyawan berpengaruh positif, apakah beban kerja berpengaruh pada kinerja karayawan melalui stress kerja, apakah beban kerja memiliki dapak pada kinerja kayawan melalui stress kerja dan motivasi kerja, apakah beban kerja memiliki dampak pada motivasi kerja melalui stress kerja. populasi penelitian ini adalah para karyawan hotel di Jember dengan sampel 120 orang, penetapan sampel dengan metode accidental sampling. Hasil penelitian ini menunjukkan bahwa variabel beban kerja memiliki pengaruh positif dan signifikan terhadap stres kerja. variabel beban kerja memiliki pengaruh nigatif dan tidak signifikan terhadap motivasi kerja. variabel beban kerja memiliki efek nigatif dan signifikan dalam kinerja karyawan secara langsung. variable stress kerja memiliki efek nigatif dan signifikan untuk motivasi kerja. variabel stres kerja memiliki efek positif dan tidak signifikan pada kinerja karyawan secara langsung. variabel motivasi kerja memiliki pengaruh positif dan signifikan terhadap kinerja karyawan secara langsung. beban kerja variabel memiliki pengaruh positif dan signifikan terhadap stress kerja secara langsung. beban kerja variabel memiliki pengaruh nigatif dan signifikan terhadap motivasi tenaga kerja melalui stres tenaga kerja. beban kerja variabel memiliki pengaruh nigatif dan signifikan terhadap kinerja karyawan melalui stres kerja dan motivasi tenaga kerja. Variabel stres kerja memiliki efek nigatif dan tidak signifikan pada kinerja karyawan melalui motivasi tenaga kerja.
\end{abstract}

Kata Kunci : beban kerja, stress kerja, motivasi kerja, kinerja karyawan

\begin{abstract}
The high workload becomes the cause of employee stress increases, this is not good for the company, especially at the level of work motivation karayawan and employee performance experiences a decline (decrease) workloadneeds to be measured so that the level of stress that wants to be caused affects well, in general work stress is divided into two of them positively affected stress and stress nigatif effect. Employee performance is a form of response to workloads provided by the company to its employees. This study aims to test whether workload variables against work stress, work motivation, employee performance have a positive effect, whether workload affects the performance of employees through work stress, whether workloads have a impact on the performance of millionaires through work stress and work motivation, whether workloads have an impact on work motivationthrough work stress. the population of this study is hotel employees in Jember with a sample of 120 people, the determination of samples by accidental sampling method. The results of this study showed that workload variableshave a positive and significant influence on work stress. workload variables
\end{abstract}


have an insignificant and insignificantinfluence on work motivation. workload variables have a significant and nigative effect in the performance of employees directly. variable stress work has a nigative and significant effect for work motivation. occupational stress variables have a positive and insignificant effect on the performance of employees directly. work motivation variables have a positive and significant influence on the performance of employees directly. variable workloadshave a positive and significant influence on work stress directly. Variable workloads have a significant and nigative influence on labor motivation through labor stress. Variable workloads have a significant and significantimpact on employee performance through work stress and workforce motivation. Occupational stress variables have an insignificant and insignificant effect on employee performance through workforce motivation

Keywords: workload, work stress, work motivation, employee performance

\section{PENDAHULUAN}

Employer adalah salah satu faktor penting yang harus dipertimbangkan Perusahaan untuk mencapai tujuan Perusahaan. Perusahaan ini di meminta kemampuannya untuk mengelola sumber daya yang direncanakan, terutama sumber daya manusia sebagai staf operasional bisnis untuk memproduksi dan menggunakan daya dalam semuakegiatan bisnis. (Ramdhani:2011).

Karyawan memperoleh tantangan memperoleh beban terhadap permintaan perusahaan yang memiliki standar kinerja tinggi untuk kelangsungan perusahaan. Perkembangan organisasi tidak dapat dipisahkan dari perubahan teknologi yang selaluberkembang untuk mendukung sistem manajemen perusahaan, baik peralatan mesing yang canggih, (baik operasional maupun administrasi). Dengan perubahan cepat, perusahaan harus beradaptasi dengan perubahan yang secepat ini. Untuk mendukung, pengembangan perusahaan, mau tidak mau, harus memperbaruinya setidaknya dengan pelatihan berkelanjutan untuk karyawan, baik baru maupun lama. (Yuli.2010)

Bahwa tantangannya sangat berat membuat karyawan tertekan atau membuat frustrasi karyawan hotel dan tidak menutup terjadinya konflik kerja yang menyebabkan ketegangan yang sering refleksikan dalam sikap dan perilaku, kritik, perlawanan, dengan tantangan lebih banyak lagi intesitasnya membuat karyawan semakin stress di tempat kerja, dengan beban kerja yang cukup tinggi telah menyebabkan kelelahan di tempat kerja, akan membuat karyawan bekerja over time dan bekerja di lingkungan perusahaan tidak nyaman. (Yuli:2010)

Teknologi yang canggih, tenaga kerja juga diharapkan setiap kontribusi yang dibekan pada perusahaan dengan meningkatkan kualitas kinerjanya yang menjadi modal dasar dan merupakan kunci keberhasilan tujuan perusahaan melalui profesionalisme, etika kerja dan produktivitas kerja, Ini diperlukan oleh pekerja dan lingkungan kerja yang sehat, aman, nyaman dan menjamin produktivitas kerja yang menjadi tumbuh.(Yuli:2010).

Stres dan beban kerja yang dialami oleh karyawan jika mereka diizinkan berkeperpanjangan tanpa likuidasi dampaknya negatif pada karyawan dan Perusahaan. Dampak negatif pada karyawan adalah penurunan kinerja kerja karyawan, misalnya, tujuan penjualan tidak tercapai, kesehatan karyawantelah menurun dan, pada akhirnya, ada suatu kondisidi mana karyawan mereka tidak dapat melakukan pekerjaan mereka. Meskipun dampak negatifnya pada perusahaan adalah penurunan pendapatan perusahaan sebagai akibat dari penurunan pekerjaankaryawan (Yuli: 2010). Di sinilah motivasi diperlukan, yaitu, sebagai roh atau dampak padapekerjaan yang berdampak pada kinerja karyawan (produktivitas tenaga kerja). 


\section{METODOLOGI}

Desain penelitian ini adalah penelitian penjelasan yang bertujuan untuk menjelaskan hubungan antara variabel dan variabel lain dan juga termasuk dalam penelitian konfirmasi (penelitian konfirmasi) karena tujuan menjelaskan hubungan kausal antara variabel melalui bukti hipotesis. (Singarimbun dan Efendi dalam Dimyati, 2009).

\section{Definisi Operasional Beban Kerja}

Webster dalam faozen. (2019) menyarankan perspektif yang berbeda tentang definisi beban kerja. Ia menyajikan beban kerja seperti a) jumlah pekerjaan atau waktu kerja yang diharapkan / diberikan kepada pekerja dan b) jumlah total pekerjaan harus diselesaikan oleh departemen atau kelompok pekerja pada periode tertentu. "Dengan definisi ini, Lysaght, et al. memberikan tiga kategori besar definisi beban kerja, yaitu, a) jumlah pekerjaan dan hal-hal yang harus dilakukan, b) waktu dan aspek-aspek tertentu dari waktu yang harus dipertimbangkan oleh pekerja dan C) psikologis subyektif. Pengalaman yang dialami oleh seorang pekerja.

\section{Definisi Operasional Stress Kerja}

Luthans (di Yulianti, 2000: 10) mendefinisikan stres sebagai jawaban dalam penyesuaian yang dipengaruhi oleh perbedaan individu dan proses psikologis, sebagai akibat dari tindakan, situasi atau peristiwa lingkungan yang memiliki terlalu banyak tuntutan psikologis dan fisik, sehingga pekerjaan stres. Dapat disimpulkan timbul karena tuntutan lingkungan dan respon masing-masing individu ketika merawatnya mungkin berbeda. Masalahmasalah stres kerja dalam organisasi Perusahaan adalah gejala penting yang diamati sejak terjadinya tuntutan menjadi efisien di tempat kerja. Sebagai hasil dari stres kerja, orang menjadi gugup, mereka merasakan kecemasan kronis, peningkatan ketegangan dalam emosi, proses pemikiran dan kondisi fisik individu. Selain itu, sebagai akibat dari keberadaan stres kerja karyawan, ia mengalami beberapa gejala stres yang dapat mengancam dan mengganggu pekerjaan mereka, seperti: Mudah marah dan agresi, mereka tidak dapat rileks, emosi yang tidak stabil, sikap tidak mau bekerja bersama, perasaan tidak dapat berpartisipasi, dan kesulitan untuk masalah tidur.

Definisi Operasional Motivasi Kerja

Motivasi berasal dari kata Latin "movere", yang berarti dorongan atau gerakan. Motivasi dalam manajemen hanya ditujukan untuk sumber daya manusia secara umum dan bawahan khususnya. Pertanyaan motivasi tentang bagaimana mengarahkan kekuatan dan potensi bawahan sehingga mereka ingin bekerja secara produktif dengan mencapai dan melaksanakan tujuan yang ditentukan (Hasibun dan Melayu, 2003: 140).

\section{Definisi Operasional Kinerja Karyawan}

Samsudin (2005: 159) menyebutkan bahwa: "Kinerja adalah tingkat implementasi tugas yang dapat dicapai oleh seseorang, unit atau divisi menggunakan kemampuan dan konfigurasi yang ada yang telah ditetapkan untuk mencapai tujuan organisasi / perusahaan". Berdasarkan pemahaman sebelumnya, dapat disimpulkan bahwa kinerja adalah kinerja yang dilakukan, menggambarkan dan memproduksi sesuatu, baik fisik maupun non-fisik, yang sesuai dengan instruksi, fungsi, dan tugas berdasarkan

Metode Mengumpulkan Data

Penelitian ini menggunakan metode kuesioner atau wawancara adalah serangkaian pertanyaan yang diberikan kepada responden yang dipilih tentang hal-hal yang berkaitan dengan tujuan penelitian. (Nazir, 2003)

Metode Analisis Data

Metode analisis data dalam penelitian ini menggunakan analisis statistik deskriptif, tes CFA, uji reliabilitas dan dengan menggunakan analisis SEM yang akan digunakan WarpPLS.7

Tes CFA dipaku untuk menguji keakuratan elemen-elemen pertanyaan utama untuk mengukur variabel investigasi. Tes reliabilitas dilakukan untuk menguji keberadaan kuisioner, ketika mengukur variabel investigasi dari kesempatan pengukuran yang konsisten. Selain itu, yaitu analisis SEM adalah ujivaliditas model, validitas analisis tergantung pada kepatuhan atau bukan asumsi yang melandasi. 


\section{HASIL DAN PEMBAHASAN}

Responden, penelitian ini adalah karyawan hotel di Jember, yang merupakan 120 orang. Karakteristik responden dibedakan tergantung pada usia dan jenis karyawan, karakteristik responden antara $<25$ tahun seperti $8 \%$ atau hingga 9 orang, antara 26 dan 35 tahun $43 \%$ atau hingga 51 , antara 36 dan 45 tahun $20 \%$ atau hingga 24 orang berusia antara 46 dan 55 tahun sebesar $28 \%$ atau hingga 33 orang dan usiaantara 56 tahun sebesar 3\% atau hingga 3 orang. Jumlah responden yang menjadi karyawan tetap dari 72 orang atau $60 \%$, jumlah responden yang menjadi karyawan non-permanen adalah 48 atau $40 \%$

(a) Combined Loading and Cross Loading. Tabel 1

Combined Loading and Cross Loading

\begin{tabular}{|c|c|c|c|c|c|c|c|}
\hline & bebankj & stress & motivasi & performa & Type (as defined) & SE & Pvalue \\
\hline$\times 2.1$ & $(0.557)$ & -0.311 & -0.561 & 0.217 & Reflective & 0.199 & 0.003 \\
\hline$\times 2.2$ & $(0.819)$ & 0.252 & 0.156 & -0.079 & Reflective & 0.124 & $<0.001$ \\
\hline$\times 2.3$ & $(0.558)$ & 0.033 & 0.555 & -0.172 & Reflective & 0.212 & \\
\hline$\times 2.4$ & $(0.426)$ & -0.095 & 0.085 & -0.027 & Reflective & 0.179 & 0.009 \\
\hline 21.2 & -0.226 & $(0.604)$ & 0.051 & -0.029 & Reflective & 0.128 & $<0.001$ \\
\hline 21.5 & -0.306 & $(0.566)$ & 0.029 & -0.172 & Reflective & 0.121 & $<0.001$ \\
\hline 21.6 & 0.458 & $(0.684)$ & -0.020 & 0.372 & Reflective & 0.107 & $<0.001$ \\
\hline 21.7 & 0.232 & $(0.840)$ & -0.070 & 0.020 & Reflective & 0.048 & $<0.001$ \\
\hline 21.8 & -0.647 & $(0.497)$ & 0.338 & -0.607 & Reflective & 0.153 & $<0.001$ \\
\hline 21.9 & -0.069 & (0.768) & -0.101 & 0.050 & Reflective & 0.084 & $<0.001$ \\
\hline 22.1 & -0.115 & 0.208 & $(0.672)$ & -0.144 & Reflective & 0.071 & $<0.001$ \\
\hline 22.2 & 0.172 & -0.199 & $(0.864)$ & 0.051 & Reflective & 0.101 & $<0.001$ \\
\hline 22.3 & 0.008 & 0.056 & $(0.828)$ & -0.150 & Reflective & 0.096 & $<0.001$ \\
\hline 22.5 & -0.145 & 0.051 & (0.585) & 0.183 & Reflective & 0.167 & $<0.001$ \\
\hline$y_{1}$ & 0.387 & -0.482 & -0.027 & (0.681) & Reflective & 0.150 & $<0.001$ \\
\hline$y^{2}$ & -0.071 & 0.146 & 0.060 & (0.787) & Reflective & 0.100 & $<0.001$ \\
\hline$y^{6}$ & -0.143 & 0.297 & 0.124 & (0.593) & Reflective & 0.159 & $<0.001$ \\
\hline$y^{8}$ & -0.160 & 0.064 & 0.010 & (0.886) & Reflective & 0.155 & $<0.001$ \\
\hline 89 & 0.132 & -0.133 & -0.234 & $(0.638)$ & Reflective & 0.107 & $<0.001$ \\
\hline
\end{tabular}

Sumber : Data diolah (output WarpPls 7.0) 2021

Variabel dengan nilai beban rendah menunjukkan bahwa indikator tidak mempengaruhi indikator reflektif > 0,7, sedangkan variabel formatifmasing-masing variabel membuat kontribusi terbesar dalam kontrak. Dalam alpha 5\% dan Tstatistik >1.97993. Beban yang dilintasi adalah ukuran lain dari validitas yang diskriminibaikan.

Hasil dari beban gabungan dan tes lintasbeban sedang menguji indikator reflektif dan pelatihan dalam penelitian ini dengan nilai $\mathrm{p}<0,001$ semua variabel penelitian, dinyatakan penting karena $<0,05$

\section{(b) Average Variance External Tabel 2 AverageVarianceExtracted}

\begin{tabular}{cccc}
\hline bebankj & stress & Motivasi & Kinerja \\
\hline 0.368 & 0.449 & 0.556 & 0.525 \\
\hline
\end{tabular}

Sumber : Data diolah (output WarpPls 7.0) 2021

Berdasarkan table diatas, menetapkan bahwa AVE itu dapat digunakan untuk mengukur banyaknya variasi pada Kostrukdibandingkan dengan varians yang terjadi dalam pengukuran. Hasil tes AVE dalam penelitian ini berjumlah 0,368 untuk beban kerja; Stres kerja bernilai 0,449; Motivasi pekerjaan bernilai 0,556; Dan kinerja karyawan bernilai 0,525 , nilai AVE telah melebihi 0,05 . Jadi nilainya telah memenuhi standar nilai AVE.

\section{(c) Model fit}

Tes ini adalah tujuan pengujian tingkat model penelitian yang memadai secara keseluruhan. Menguji pentingnya variable independen dalam uji variable dependen dapat diatur secara signifikan ketika menggambarkan apakah nilai $\mathrm{P}$ kurang dari 0,05. Berikut ini adalah output dari model indeks penyesuaian yang disajikan dalam tabel, yaitu:

\section{Tabel 3}

Model Fit Indices

\begin{tabular}{|c|c|c|c|c|}
\hline Model & $\begin{array}{r}\text { Fit } \\
\text { Indices }\end{array}$ & $\begin{array}{r}\mathbf{P} \\
\text { Values } \\
\end{array}$ & Kriteria & Keterangan \\
\hline APC & 0.354 & $<0.001$ & $\mathrm{p}<0,05$ & Diterima \\
\hline ARS & 0,287 & $<0.001$ & $\mathrm{P}<0,05$ & Diterima \\
\hline R-Squared & 0.275 & $<0.001$ & $\mathrm{P}<0,05$ & Diterima \\
\hline AVIF & 1.502 & $\begin{array}{c}\text { Goodif }< \\
5 \\
\end{array}$ & $\begin{array}{c}\mathrm{AVIF}< \\
5 \\
\end{array}$ & Diterima \\
\hline GoF & 0.369 & \multicolumn{2}{|c|}{$\begin{array}{c}\text { small } \geq 0,1, \text { medium } \\
\geq 0,25, \text { large } \geq 0,36\end{array}$} & Large \\
\hline SPR & 0.833 & \multicolumn{2}{|c|}{$\geq 0,7$ dan idealnya $=1$} & Diterima \\
\hline RSCR & 0.962 & \multicolumn{2}{|c|}{$\geq 0,9$ dan idealnya $=1$} & Diterima \\
\hline SSR & 0.833 & \multicolumn{2}{|c|}{$\geq 0,9$} & Ditolak \\
\hline NLBCDR & 1.000 & \multicolumn{2}{|c|}{$\geq 0,7$} & Diterima \\
\hline
\end{tabular}

Sumber: Data diolah (output WarpPls 7.0) 2021

Hasil output di tabel sebelumnya, jelaskan bahwa APC memiliki indeks 0,354 dengan nilai $\mathrm{p}<0,001$. Sementara ARS memiliki indeks 0,287 denga nnilai $p<0,001$. Berdasarkan criteria tersebut, APC telahm emenuhi criteria karena memilik inilai $p$ 
$<0,001$. Demikian pula, nilai $\mathrm{p}$ dari ARS adalah $\mathrm{p}<0,001<0,05$. Nilai AVIF yang harus $<5$ telah dipenuhi karena didasarkan pada data AVIF 1.502. Data penelitian diuji dengan model penyesuaian dan data penelitian dinyatakan dengan cara sehingga data penelitian ini tidak akan terjadi multi coliirearite. Dengan demikian, model inner model dapat diterima.

\section{(d) Path coefficient and P-values}

Pada bagian ini, menjelaskan setiap jalur di bagian model menggunakan analisis jalur (Path coefficient). Setiap jalur yang terbukti menunjukkan efek langsung dan tidaklangsung dari beban kerja (X1), stress kerja (Z1), motivasi kerja (Z2), kinerja karyawan (Y) di Hotel Jember. Nilai koefisien jalur dapat dilihat pada tabelberikut:

Tabel 4

Nilai Koefisien Jalur Pengaruh Langsung

\begin{tabular}{|c|c|c|c|c|c|}
\hline & & & $\begin{array}{l}\text { Estimat } \\
\mathrm{e}\end{array}$ & $P$ & Label \\
\hline stress & $<$ & $\begin{array}{l}\text { bebank } \\
\text { j }\end{array}$ & 0,583 & ' 001 & $\begin{array}{l}\text { signifika } \\
\mathrm{n}\end{array}$ \\
\hline motiv & $<$ & $\begin{array}{l}\text { bebank } \\
\text { j }\end{array}$ & $-0,248$ & ' 060 & tidak \\
\hline $\begin{array}{l}\text { kinerj } \\
a\end{array}$ & $<$ & $\begin{array}{l}\text { bebank } \\
\text { j }\end{array}$ & $-0,364$ & $\begin{array}{l}, 00 \\
1\end{array}$ & $\begin{array}{l}\text { signifika } \\
\mathrm{n}\end{array}$ \\
\hline motiv & $<$ & stress & $-0,273$ & $\begin{array}{l}, 01 \\
1\end{array}$ & $\begin{array}{l}\text { signifika } \\
\mathrm{n}\end{array}$ \\
\hline $\begin{array}{l}\text { kinerj } \\
a\end{array}$ & $<$ & stress & 0,234 & $\begin{array}{l}, 05 \\
6\end{array}$ & tidak \\
\hline $\begin{array}{l}\text { kinerj } \\
a\end{array}$ & $\begin{array}{l}< \\
-\end{array}$ & motiv & 0,420 & $\begin{array}{l}, 00 \\
1\end{array}$ & $\begin{array}{l}\text { signifika } \\
\mathrm{n}\end{array}$ \\
\hline
\end{tabular}

Sumber: Hasil Pengolahan data 2021

a. Pengaruh Variabel beban kerja (X) terhadap stress Kerja (Z1)

Berdasarkan Tabel 4 Anda dapa tmelihat untuk menguji variable beban kerja $(\mathrm{X})$ pada stress kerja yang diperoleh dengan nilai beta ( $\beta$ ) 0,583 dengan $\rho$-value 0,001 . Karena nilai $\rho$ nilai kurang dari $\alpha(0,05)$, H0 ditolak, oleh karena itu, ada efek positif yang signifikan dari beban kerja $(\mathrm{X})$ untuk bekerja tegangan (Z1). b. PengaruhVariabel beban kerja (X) terhadap motivasi kerja (Z2)

Berdasarkan Tabel 4 Anda dapat melihat untuk menguji variable beban kerja (X) dalam motivasi kerja (Z2) yang diperoleh dengan nilai beta $(\beta)$ dari $-0,248$ dengan $\rho$-velue 0,060 . Karena nilai $\rho$-nilailebihbesardari $\alpha$ $(0,060<0,05)$, ha ditolak, sehingga ada efek nigatip pada beban kerja yang signifikan (X) dalam motivasi kerja (Z2).

c. Pengaruh Variabel beban kerja (X) terhadap kinerja karyawan (Y)

Berdasarkan Tabel 4, dapat dilihat untuk menguji variable beban kerja (X) dalam kinerja karyawan $(\mathrm{Y})$ yang diperoleh dengan nilai Beta $(\beta)-0,364$ dengan $\rho$-velue 0,001 . Karena nilai $\rho$-nilai lebih kecil dari $\alpha(0,001$ $<0,05)$, ha kemudian diterima, sehingga ada efek signifikan dari negatip (x) dalam kinerja karyawan (Y).

d. Pengaruh Variabel stress kerja (Z1) terhadap motivasi kerja (Z2)

Berdasarkan Tabel 4 dapat dilihat untuk menguji stress kerja variabel (Z1) yang diperoleh dengan nilai beta $(\beta)$ dari -0.273 dengan $\rho$-velue 0,011 . Karena nilai $\rho$ nilai kurang dari $\alpha(0,011<0,05)$, kemudian diterima, karena ada pengaruh signifikan dari stress kerja nigatip (Z1) kemotivasi kerja (Z2).

e. Pengaruh Variabel stress kerja (Z1) terhadap kinerja karyawan (Y)

Berdasarkan Tabel 4 dapat dilihat untuk menguji variable stress tenaga kerja (Z1) dalam kinerja karyawan $(\mathrm{Y})$ memperoleh nilai beta $(\beta) 0,234$ dengan nilai $\rho$-velue 0,056 . Karena nilai $\rho$ nilai lebih besar dari pada $\alpha \quad(0,056<0,05)$, H0 diterima, sebagaimana diterima, oleh karenaitu, ada pengaruh positif, tetapi itu bukan stress kerja yang signifikan (Z1) dalam kinerja karyawan (Y).

f. Pengaruh Variabel motivasi kerja (Z2) terhadap kinerja karyawan (Y)

Berdasarkan Tabel 4 dapat dilihat untuk menguji variable motivasi kerja (Z2) dalam 
kinerja karyawan $(\mathrm{Y})$ memperoleh nilai beta ( $\beta$ ) 0,420 dengan nilai $\rho$-velue 0,001 . Karena nilai $\rho$-nilai lebih kecil dari $\alpha(0,001<0,05)$, oleh Oleh karena itu, H0 ditolak, oleh karenaitu, ada efek positif yang signifikan dari stress kerja (Z) pada kinerja karyawan (Y).

\section{(e) Model Struktural}

Bagian ini menjelaskan perhitungan pengaruh konflik kerja variabel (x) dalam kinerja karyawan (Y) dengan stress karyawan (Z1) dan motivasi kerja (Z2) sebagai variabel intervening, dan hasil koefisien dari koefisien jalur yang menghasilkan koefisien jalur disajikan sebagai berikut:

Gambar 1

PathCoefficient dan P-Values

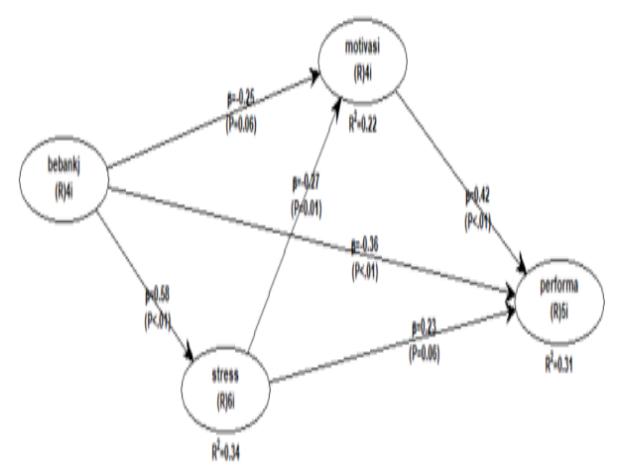

Sumber: Hasil Pengolahan data 2021

Dengan mendasarkan pengujian koefisien jalur seperti pada tabel 4, maka model dalam bentuk diagram pathhasil pengujian koefisien jalur disajikan pada gambar 1, model tersebut juga dapat dinyatakan dalam bentuk persamaan (system persamaan simultan). Analisis jalur dalam bentuk persamaan disajikan sebagai berikut:

Z1 stress kerja $=0,583$ bebankerja

Z2motiv kerja $=0,25$ bebankerja

Z2motiv kerja $=0,58$ bebankerja $+0,27$ stress

Y kinerja $=0,36$ bebankerja

Y kinerja $\quad=0,58$ bebankerja +

0,23 stress

Y kinerja $\quad=0,25$ bebankerja+

0,42 motivasi
Y kinerja $\quad=0,58$ bebankerja $+0,27$ stress

$+0,42$ motivasi

(f) PerhitunganKoefisien Jalur PengaruhTidak Langsung

Tes pengaruh tidak langsung dilakukan dengan mengamati hasil tes rute yang disetujui, jika semua rute ditusuk secara signifikan, pengaruh tidak langsung juga signifikan, dan jika ada jalan yang tidak signifikan, tidak langsung. efek. Dikatakan bahwa itu tidak signifikan. Koefisien rute tidak disajikan langsung pada Tabel 5

Tabel 5

Pengujian Perngaruh Variabel Intervening

\begin{tabular}{|c|c|c|}
\hline & $\begin{array}{l}\text { bebankj - } \\
\text { Kinerja } \\
\text { karyawan }\end{array}$ & $\begin{array}{l}\text { stress - Kinerja } \\
\text { karyawan }\end{array}$ \\
\hline $\begin{array}{l}\text { Pengaruh } \\
\text { Langsung }\end{array}$ & $=-0,364$ & $=0,234$ \\
\hline $\begin{array}{l}\text { Pengaruh Tidak } \\
\text { Langsung }\end{array}$ & $\begin{array}{l}=0,583+(- \\
0,407)+(- \\
0,398) \\
=-0,222\end{array}$ & $\begin{array}{l}=-0,273+0,120 \\
=-0,153\end{array}$ \\
\hline $\begin{array}{l}\text { P valuesfor total } \\
\text { effects }\end{array}$ & 0,001 & 0,223 \\
\hline Pengaruh Total & $\begin{array}{l}=-0,364+(- \\
0,222) \\
=-0,586\end{array}$ & $\begin{array}{l}=0,234+(-0,153) \\
=0,081\end{array}$ \\
\hline Kesimpulan & \multicolumn{2}{|c|}{$\begin{array}{l}\text { Pengaruh langsung > Pengaruh } \\
\text { tidak langsung : Variabel } \\
\text { bebankerjabersinergi dengan } \\
\text { variabel stress kerja, motivasi } \\
\text { kerja untuk meningkatkan kinerja } \\
\text { karyawan di hotel di Jember }\end{array}$} \\
\hline
\end{tabular}

Sumber: Hasil Pengolahan data 2021

Dari informasi yang disajikan dalam Tabel 5, diketahui bahwa pengaruh konflik kerja terhadap kinerja karyawan masingmasing memiliki pengaruh langsung yang sama besar dari pengaruh tidak langsungnya, artinya stress dan motivasi kerja bersinergi dengan variabel konflik kerja dalam meningkatkan kinerja karyawan di hotel di jember. Lebih jelasnya sebagai berikut:

a. Beban kerja berpengaruh positif terhadap kinerja pegawai melalui stress kerja dan motivasi kerja (sebagai intervening) 
Berdasarkan Tabel 5 dapat dilihat untuk menguji beban kerja (X) dalam kinerja karyawan (Y) melalui variator perantara (streskerja dan motivasi kerja) (Z) diperoleh dengan nilai beta $(\beta)$ dari $\rho$-Value 0,001 . Karena nilai $\rho$-value kurang dari $\alpha(0,001$ $<0,05)$, Oleh karenaitu, H0 ditolak, oleh karenaitu, adaefeknigatif yang signifikan dari beban kerja (X1) dalam hasil karyawan (Y). Melalui variator perantara (stress kerja dan pekerjaan motivasi) $(\mathrm{Z})$

b. Stress kerja berpengaruh positif terhadap kinerja pegawai melalui motivasi kerja (sebagai intervening)

Berdasarkan Tabel 5 dapat dilihat untuk menguji variabel stres tenaga kerja (Z1) dalam kinerja karyawan (Y) melalui variabel perantara (motivasi kerja) (Z2) yang diperoleh dengan nilai beta $(\beta) 0,081$ dengan nilai $\rho$-velue 0,223 . Karena nilai $\rho$-velue lebih besar dari $\alpha(0,223<0,05)$, H0 diterima, oleh karena itu, ada efek positif, tetapi ini bukan tegangan kerja yang signifikan (Z1) dalam kinerja karyawan (Y) melalui variator perantara

( Motivasi kerja) (Z2)

Hal tersebut dikarenakan bebankerjayang ada di hotel jember memiliki dampak nigatif kepada kinerjakaryawan, dengan adanya bebankerjayang overload menjadi stress kerja dan motivasi kerja secara extrinsic memberikan pengaruh pada kinerja karyawan dalam menjalanka npekerjaanya.

\section{(g) KoefisienDeterminasi}

Koefisien determinasi adalah besarnya yang menunjukkan variasi besarnya variabel dependen yang dapat dijelaskan oleh variabel independen. Dengan kata lain, koefisien determinasi ini digunakan untuk mengukur seberapa jauh variabel bebas untuk menjelaskan variabel dependen. Koefisien determinasi dalam penelitian ini adalah sebagai berikut:

Tabel 6

Koefisien Determinasi, BebanKerjaTerhadap

Stress Kerja

Model Summary $^{\text {b }}$

\begin{tabular}{|c|r|r|}
\hline Model & \multicolumn{1}{|l|}{ R Square } & Adjusted R Square \\
\hline 1 &, 340 &, 334 \\
\hline
\end{tabular}

a. Predictors: (Constant), bebankj

b. DependentVariable: stress kerja

Sumber: Lampiran

Pengaruh $\quad \epsilon 1 \quad$ (variabel selain, konflikkerja terhadap stress kerja)

$$
\begin{aligned}
& =\sqrt{ } 1-\mathrm{R}^{2} \\
& =\sqrt{ } 1-0,334^{2} \\
& =\sqrt{ } 1-0,116 \\
& =0,884 \text { atau } 88,4 \%
\end{aligned}
$$

Tabel 7

Koefisien Determinasi, BebanKerjaDan

Stress KerjaTerhadap MotivasiKerja Model Summary ${ }^{b}$

\begin{tabular}{|c|r|r|}
\hline Model & R Square & Adjusted R Square \\
\hline 1 &, 215 &, 202 \\
\hline
\end{tabular}

a. Predictors: (Constant), bebankerja dan stress kerja

b. DependentVariable: motivasikerj

Sumber: Lampiran

Pengaruh $\quad \epsilon 1 \quad$ (variabel selain, konflikkerja dan stress kerja terhadap motivasikerja)

$$
\begin{aligned}
& =\sqrt{ } 1-\mathrm{R}^{2} \\
& =\sqrt{ } 1-0,202^{2} \\
& =\sqrt{ } 1-0,041 \\
& =0,959 \text { atau } 95,9 \%
\end{aligned}
$$


Tabel 8

Koefisien Determinasi, BebanKerja,Stress KerjadanMotivasiKerjaTerhadap Kinerja

Karyawan

Model Summary ${ }^{\mathrm{b}}$

\begin{tabular}{|c|r|r|}
\hline Model & R Square & Adjusted R Square \\
\hline 1 &, 307 &, 288 \\
\hline
\end{tabular}

a. Predictors: (Constant), bebankerja, stress kerja dan motivasikerja

b. DependentVariable: kinerjakaryawan Sumber: Lampiran

Pengaruh $\quad \epsilon 1 \quad$ (variabel selain, konflikkerja, stress kerja dan motivasikerja terhadap kinerjakaryawan)

$$
\begin{aligned}
& =\sqrt{ } 1-\mathrm{R}^{2} \\
& =\sqrt{ } 1-0,288^{2} \\
& =\sqrt{ } 1-0,083 \\
& =0,917 \text { atau } 91,7 \%
\end{aligned}
$$

Koefisien determinasi Total :

$$
\begin{gathered}
R_{m}^{2}=1-P_{e 1}^{2} P_{e 2}^{2} P_{e 3}^{3} \\
R_{m}^{2}=1-(0,884)^{2} \cdot(0,959)^{2} \cdot(0,917)^{2} \\
=1-(0,781 \cdot 0,920.0,841) \\
=1-0,604 \\
=0,396
\end{gathered}
$$

Hasil perhitungan SEM dapat diketahui bahwa koefisien determinasi R2 total diperoleh nilai sebesar 0,396. Hal ini berarti $39,6 \%$ variasi variabel bebankerja $(X)$, stresskerja (Z1), motivasi kerja (Z2), kinerjakaryawan (Y), sedangkan sisanya sebesar $60,4 \%$ diterangkan oleh variabel lain dan error yang tidak dijelaskan dalam penelitian ini.

\section{KESIMPULAN}

Beban kerja secara langung mempengaruhi kinerja karyawan secara nigatif, dengan adanya beban kerja justru karyawan mengalami stress kerja ini terbukti dalam penelitian ini, juga berdampak pada motivasi kerja yang mempengaruhi secara nigatif juga, sedangkan motivasi secara langsung mempengaruhi kinerja secara signifikan.

\section{DAFTAR PUSTAKA}

Faozen. 2019. Work Stress: Antesedent Variables And Its Impact On Employee Motivation And Performance (Case Study At The University Of Muhammadiyah Jember). ICOGISS 2019.1, pp.536553. Jember: jurnal.unmuhjember.ac.id. doi:http://dx.doi.org/10.32528/pi.v0 i0.2521.

Ramdhani 2011, Pelaksanaan Program Pelatihan dan Kompetensi Pengaruhnya Terhadap Kinerja Karyawan di PT Otto Phrmaceutical Industries, Tesis Magister Manajemen ,Universitas Bina Nusantara.

Yuli Tania,2010, Analisis Pengaruh Stress Kerja, Konflik Kerja Dan Motivasi Kerja Terhadap Kinerja Karyawan Pada Pt. Cempaka Bersamamaju, Tesis Magister Manajemen ,Universitas Bina Nusantara.

Yulianti Praptini, 2000. Pengaruh SumberSumber Stres Kerja Terhadap Kepuasan Kerja Tenaga Edukatif tetap Fakultas Ilmu Sosial Universitas Airlangga Di Surabaya. Tesis tidak diterbitkan. Surabaya : Program Pascasarjana Ilmu Manajemen Universitas Airlangga

Dimyati. 2009. Belajar dan Pembelajaran. Jakarta: RinekaCipta

Hasibuan, S.P. Melayu, 2003, MSDM, EdisiRevisi, Jakarta ,PT. Bumi Aksara,

Samsudin. 2005. Manajemen Sumber Daya Manusia. Bandung Pustaka Setia

Nazir,M. 2003. Metode Penelitian. Jakarta :Ghalia Indonesia 